\title{
CIKLÁMEN TERMESZTÉSÉNEK VIZSGÁLATA
}

\section{ANALYSIS OF GROWING CYCLAMEN PERSICUM}

\author{
Turiné Farkas Zsuzsa ${ }^{1 *}$, Palkovics András², Jóljárt Fanni ${ }^{3}$ \\ 1,2,3 Kertészeti és Vidékfejlesztési Kar, Neumann János Egyetem, Magyarország \\ https://doi.org/10.47833/2020.2.AGR.008
}

\section{Kulcsszavak: \\ fajták, \\ levélszám, \\ bimbószám, \\ virágszám, \\ növényátmérö \\ Keywords: \\ varieties, \\ number of leaves, \\ number of buds, \\ number of flowers, \\ diameter}

\section{Cikktörténet:}

Beérkezett

Átdolgozva

Elfogadva
2019. szept. 25.

2020. február 26.

2020. március 5 .

\begin{abstract}
Összefoglalás
A ciklámen az egyik legkeresettebb virágos cserepes dísznövényünk. Közel egy évszázada termesztik hazánkban, elsősorban az őszi és téli hónapokban keresik a piacon. Nagy fajtaválasztékkal rendelkezik. A hagyományos (homozigóta) fajták termetesebbek, egyszerre kevesebb, de nagyobb virágot hoznak, színük gyakran élénk. Tenyészidejük 9-10 hónap.

Az F1-hibrid fajták tenyészideje rövidebb, 8,5 hónap körüli. Sokkal intenzívebben virágoznak, változatos színskálájukban rendkívül dekoratív pasztellszínek sorakoznak. Az utóbbi időben egyre népszerübbek a minifajták. Ezek tenyészideje 1 hónappal rövidebb, kisebb helyigényük miatt gazdaságosabban termeszthetők. Kutatásunk célja a fajták díszítő értékének vizsgálata.
\end{abstract}

\begin{abstract}
The cyclamen is one of the most sought potted ornamental plants. It has been grown in our country for almost a century. It is searched mainly the winter and autumn months on the market. It has huge variety selection. The traditional (homozygote) varieties are more voluminous. They have less but bigger flowers at the same time and their color is usually bright. Their breeding season is 9-10 months. The breeding season of $F 1$ varieties is shorter approximately 8,5 months. They bloom more intensively. They have various range of colors with decorative pastel colors. Mini-varieties have become more popular lately. Their breeding season is shorter with 1 months and their space requirement is smaller. Therefore we can product them more economical. The purpose of our research to examine the ornamental value of varieties.
\end{abstract}

\section{Bevezetés}

Napjainkban a szabadföldi dísznövénytermesztés mellett egyre inkább teret kap a növényházi dísznövénytermesztés is, ezen belül pedig a cserepes dísznövények termesztése. A beltéri dekorációként használt cserepes virágos dísznövények nagyon látványosak, de csak időszakos díszt adnak. Nyílásuk csak pár hétre korlátozódik, ezért felhasználásuk inkább szezonális jellegű, ajándékozási szokáshoz vagy jeles naphoz kötődik.

\footnotetext{
* Kapcsolattartó szerző. Tel.: +36 76517635

E-mail cím: turine.zsuzsa@kvk.uni-neumann.hu
} 
A ciklámen hazánk piacán az egyik legkeresettebb cserepes dísznövénynek tekinthetö. Termesztése közel egy évszázados múltra tekint vissza és a szokásoknak megfelelően elsősorban az őszi és téli hónapokban keresik a piacon. Termesztése az elmúlt években jelentősen lerövidült, korszerüsödött a technológiai fejlödésnek köszönhetően [9]. Jelentösége annak köszönhetö, hogy nagyon dekoratív növény, virágzása pedig egészen augusztustól decemberig tart, ezért egy hosszan értékesíthető kultúrának számít.

Igényes, intenzív termesztési igényű, nagy hozamra képes kultúra, ám igen költséges is egyben. Ugyanakkor a növekvő piaci verseny miatt a termelőknek egyre inkább fontos a kifogástalan minőség előállítása, az újdonságok alkalmazása pl.: egy-egy új fajta kipróbálása, hogy versenyképesek lehessenek más termesztőkkel szemben [6].

Rendszertanilag a Primulaceae család Cyclamen nemzetségébe tartozik, összesen 20 faja ismert. Kertészeti szempontból legjelentősebb faj a Cyclamen persicum, a KeletMediterráneumban, így Krétán, Cipruson és más szigeteken, illetve Líbiában honos [4].

A Cyclamen persicum egy alacsony növésü évelő, szárgumós növény, melynek átmérője 2-3 $\mathrm{cm}$, alul gyökeres. A gumó parás kérgü. A levéllemezek 3-8 $\mathrm{cm}$ hosszúak, szélük ép, vagy enyhén hullámos. A levelek szív alakúak, ízlésesen ezüstös mintázatúak, fonákjuk rozettás, bíboros. Illatos virágú, a párta vöröses rózsaszín vagy bíboros, a pártacimpák 10-20 mm hosszúak, a bibeszál kinyúlik a pártából [1], [5].

Az említett mediterrán területeken az alacsony hegyekben él, mészkő alapú humuszos erdei talajokon. A mélyárnyéki erdők aljnövénye, így ez fogja meghatározni környezeti igényeit is termesztésénél, ahol kondicionált körülményeket kell számára biztosítanunk. Igen fontos tényezök: a hőmérséklet, a fény, a víz és a páratartalom, valamint a talaj és a tápanyag biztosítása [11].

Szaporítását magvetéssel végzik. A magok csak megfelelő szelekció és nemesítési munka útján kerülnek használatba. Ahhoz, hogy a mag megfelelő minőségü legyen, elengedhetetlen a nagy biológiai érték, az igazolt származás és a fajtaazonosság. Éppen ezért manapság a magok termesztését csak a nemzetközileg is elismert, nagy magtermesztő cégek végzik pl: Németországban, Hollandiában vagy Franciaországban [9]. Napjainkban az intenzív termesztésben a termesztők a már kész palántákat vásárolják meg a szaporítóanyag termesztő cégektöl és ezt nevelik tovább, lerövidítve ezzel az adott kultúra termesztési idejét.

A palántákat tálcában forgalmazzák, a termesztők ebben tartják öket kondicionált körülmények között egészen az ültetés időpontjáig. Ebben az időszakban fontos az optimális vízellátás, hiszen a kis növények könnyen kiszáradhatnak és mivel rendkívül szorosan vannak sokáig nem tárolhatók, mert szöveti megnyúlás következik be és a gombás betegségek is kialakulhatnak a szellőzés hiányában.

A magoncok cserepezési ideje a termesztés időzítésének függvénye. Az augusztus végi, szeptember eleji fajtákat tavasszal ültetjük el. Azonban a fő értékesítési időszak ősszel és tél elején van, ezért a ciklámenek zöménél az ültetés nyár elejére esik [9]. A palántákat méretüktöl függően 10,5-13 cm átmérőjű cserepekbe ültetjük. Fontos, hogy a gumó mindig a talajfelszín alá kerüljön, se túl magasan, se túl mélyen ne legyen. A fedetlen gumó kiszárad, ennek hatására berepedezik, utat nyitva ezzel különféle fertőzéseknek [12].

A mély ültetés akadályozza a bimbóképződést, a magas ültetés nem kívánatos korai virágzást eredményez [2]. Tehát megállapítható, hogy a palánták ültetése igen nagy körültekintést igényel. Ez a napjainkban jelentkező munkaerőhiány és képzetlenség miatt igen nagy gondot jelenthet a termesztők számára.

A beültetett növényeket kezdetben szoros térállásban helyezzük el árnyékoló alatt, ügyelve a megfelelő párásításra és szellőztetésre. Az árnyékolás megvédi a növényeket az erős sugárzástól és a túlzott vízveszteségtől. Az árnyékolásra napjainkban nagy hangsúlyt kell fektetni a globális klímaváltozás következtésben, a növényházakban már nem elegendő belső árnyékolást használni és a gyakran használatos Raschel-háló sem mindig hatásos. Helyette érdemes alkalmazni a fóliák külső árnyékolását fehér festékkel. Elönye, hogy a fehér festés egyfajta homogén szürőként müködik, ezáltal a legjobb minőségü szórt fényt eredményezi a termesztőberendezésben. Ennek következtében a növények levele és közege nem szenved stresszt az erös fény hatására, melynek eredménye az egyöntetübb, homogénebb minőség lesz. $E$ módszer segítségével a fóliaházak hőmérséklete nyáron átlagosan $22-24{ }^{\circ} \mathrm{C}$ között tartható. $\mathrm{Az}$ öszi 
időszaktól a fényintenzitás csökkenésével a fehér festéket oldószerrel el kell távolítani, hogy a fényintenzitás tartható legyen [8].

6 hét elteltével, amikor a növények lombja összeér szükséges a cserepeket szétrakni kb. 30 $\mathrm{db} / \mathrm{m}^{2}$-re, majd 4-6 hét múlva a műveletet meg kell ismételni $15 \mathrm{db} / \mathrm{m}^{2}$-es térállás kialakításával. Ez a müvelet rendkívül fontos a ciklámen esetében, hiszen csak megfelelö térállás esetén lesznek megfelelöen kompakt, tömör állományúak a növények, mely a ciklámen díszítőértékét is meghatározza. Ha a térállás szük, a növények levelei deformálódnak, a növényi szövetek pedig megnyúlnak, teret engedve ezzel különböző betegségek megjelenésének is [9].

Másik fontos művelet az elhalt növényi részek, elnyílt virágok eltávolítása. Erre elsősorban növényvédelmi okok miatt van szükség, mivel az elhalt növényi részek botritisz fertőzést okozhatnak. Szintén fontos a növények egyenletes víz és tápanyagellátása is egészen a posztharveszt tevékenység megkezdéséig [2].

Megállapítható tehát, hogy a ciklámen egy igen intenzív termesztést igénylő nehéz kultúra, melyben fontos szerepet tölt be a növényvédelem is. A cikláment számos kórokozó és kártevő támadhatja meg, nemcsak rontva ezzel a növények díszítőértékét, de jelentős anyagi kárt is okozva ezzel.

A ciklámen föbb kórokozói: Botrytis (szürkepenész), Thielaviopsis, Fusarium, Cryptocline, TSW, Erwinia és a Pythium [13]. Általánosságban elmondható, hogy ezeknél a betegségeknél fontos a megfelelő megelőzés, mely magában foglalja a megfelelő szellőztetést, megfelelő hömérséklet tartását a termesztö-berendezésben, a növények szellős elhelyezését és a növényi lomb szárazon tartását. A ciklámen a különböző kártevőkre is fogékony, mint pl.: a ciklámen atka és a tripsz. Ezen kártevők elsősorban a virág-levél díszítőértékben okoznak kárt szívogatásukkal. A levelek penderednek, a virágok deformálódnak és szélük színeződik. Védekezni ellenük különféle rovarölö szerekkel lehet pl.: Mospilan, Vertimec [3], [12].

A dísznövénytermesztés területén is kiemelt fontosságú a fogyasztói szokások átalakulásának megfelelő ismerete, hiszen a keresleten alapuló értékesítés és a célzott termelés ezen ismeretek hiányában nem lehet kellöképpen sikeres [7].

A ciklámen értékesítési fázisa akkor kezdődik, amikor a tövek virágzásnak indulnak. Általában 2-6 db nyílott virág esetén mondhatjuk a ciklámeneket piacosnak. A kész növényeket fölszedik, áruvá készítik és csomagolják, majd CC-kocsikon szállítják az értékesítés helyszínére. Hazánkban a csomagolás eszköze általában különböző kartondoboz vagy tálca, melyben méret, fajta és magasság szerint csoportosítják a növényeket [12].

Érdemes kihangsúlyozni a dísznövénytermesztésben a díszítőérték fontosságát, hiszen hazánkban is egyre nagyobb a piaci verseny a különböző növényházi kultúrák terén is. Ezért is fontos az egyes fajták értékmérő tulajdonságainak megfelelő ismerete a termesztésben.

\section{Anyag és módszer}

A kísérletet a tiszakécskei Gulyás Kertészetben állítottuk be 2018. augusztus 20-án.

A vállalkozás legföképpen egy-, és kétnyári növények termesztésével és értékesítésével foglalkozik, de ezen kívül megtalálható még a kínálatban pl.: a ciklámen, bizonyos évelő lágyszárú dísznövények és balkonnövények is. A kertészet a termesztés mellett nagy hangsúlyt fektet az otthoni értékesítésre is, köszönhetően a tranzit üvegházak elterjedésének, melyekben nem csak termesztést, hanem értékesítést is folytatnak. Ez határozza meg a kertészet felépítését is. A termesztő felület $5000 \mathrm{~m}^{2}$ nagyságú fóliaház, melynek elrendezése blokk rendszerü, kiszolgálva ezzel az értékesítést is. A blokk első felében történik a tényleges eladás, ahova a vevők is beléphetnek. A fóliaházban asztalok találhatóak, melyek füthetők és szívatószövettel borítottak a növények optimális vízfelvétele érdekében. A ház fütését gáz és vegyes tüzelésű kazánok látják el. Az öntözés fúrt kútból történik, nagy teljesítményű szivattyúkkal.

A kísérlet az egyik fütött asztalon lett beálítva 2018. augusztus 20-án. A nagy meleg elleni védelmet a fent hagyott belső fólia látta el. Összesen $160 \mathrm{db}$ növényt, két miniciklámen fajtát vizsgáltunk a Super-serie fajtasorozatból: a 'Miniwinter' és a 'Picasso' fajtákat. Ezek véletlenszerű blokkos elrendezésben kerültek a kísérlet helyszínére. Egy 10-es blokkot egy tábla jelöl. A növényeket az első bimbók megjelenésétöl kezdve mértük 2 hetente, összesen 4 alkalommal. 
Mérési paraméterek: a virágok, bimbók, levelek száma és a növények átmérője. A mért adatokat Microsoft Excel táblázatban rögzítettük, majd varianciaanalízissel kiértékeltük.

\section{Eredmények}

A 2018-ban elvégzett kísérlet, mely a két miniciklámen fajta közötti értékmérö tulajdonságokat vizsgálta szignifikáns eredményeket adott. A 'Miniwinter' és a 'Picasso' fajták között különbségek mutathatók ki a méret, tömörség, a virágzás ideje és mértéke között is, mely fontos információt nyújthat a termesztő számára.

\subsection{Növényátmérő}

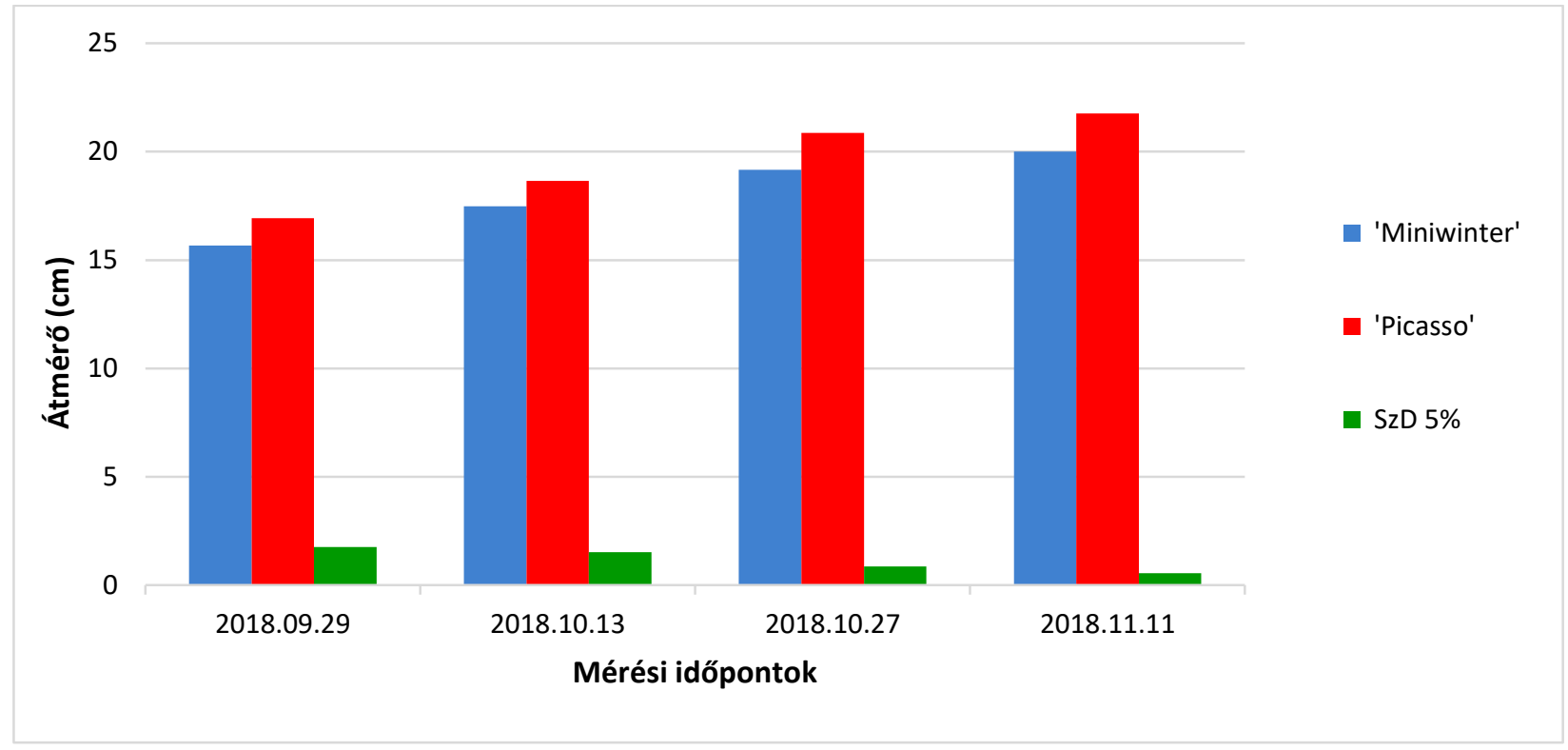

1. ábra: Ciklámen fajták átmérőjének alakulása 2018-ban

Forrás: saját ábra

$A z$ 1. ábra szerint a ciklámenek átmérője két hetenként, összesen négy alkalommal lett mérve. Jól látható az ábrán, hogy a 'Picasso' fajtájú miniciklámenek a tenyészidő folyamán mindig nagyobbak voltak pár cm-rel mint a 'Miniwinter' fajta egyedei. Az október 27-én és a november 10-én kapott eredmények mutatnak szignifikáns különbséget, a 'Picasso' fajta növényei szignifikánsan nagyobb átmérővel rendelkeztek 


\subsection{Bimbók száma}

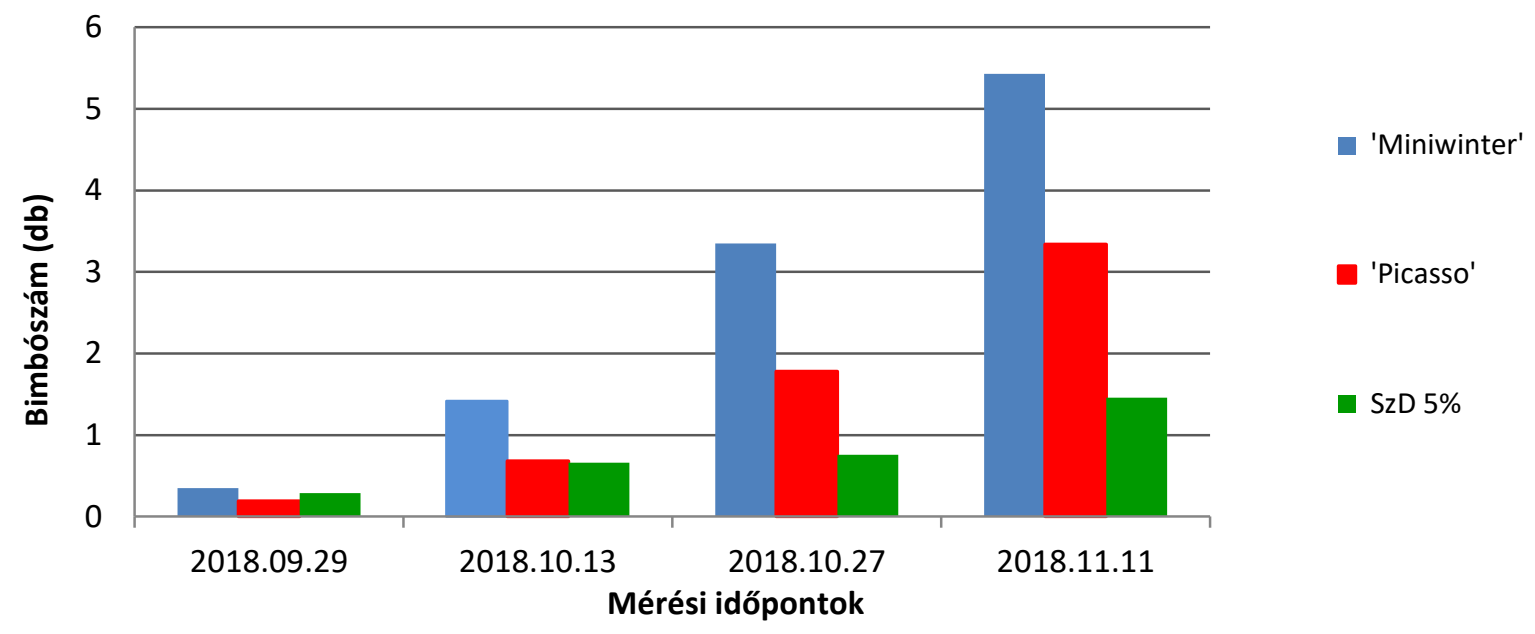

2. ábra: Ciklámen fajták bimbószámának alakulása 2018-ban

Forrás: saját ábra

A ciklámenek bimbószámának értékei a 2. és 4. mérési időpontokban adtak szignifikáns eltérést (2. ábra). Ez alapján elmondható, hogy a 'Miniwinter' átmérője bár kisebb, magasabb a bimbók száma a mért időpontokban. Ebből kifolyólag a virágok száma és a virágzás ideje is eltérő lehet.

\subsection{Virágok száma}

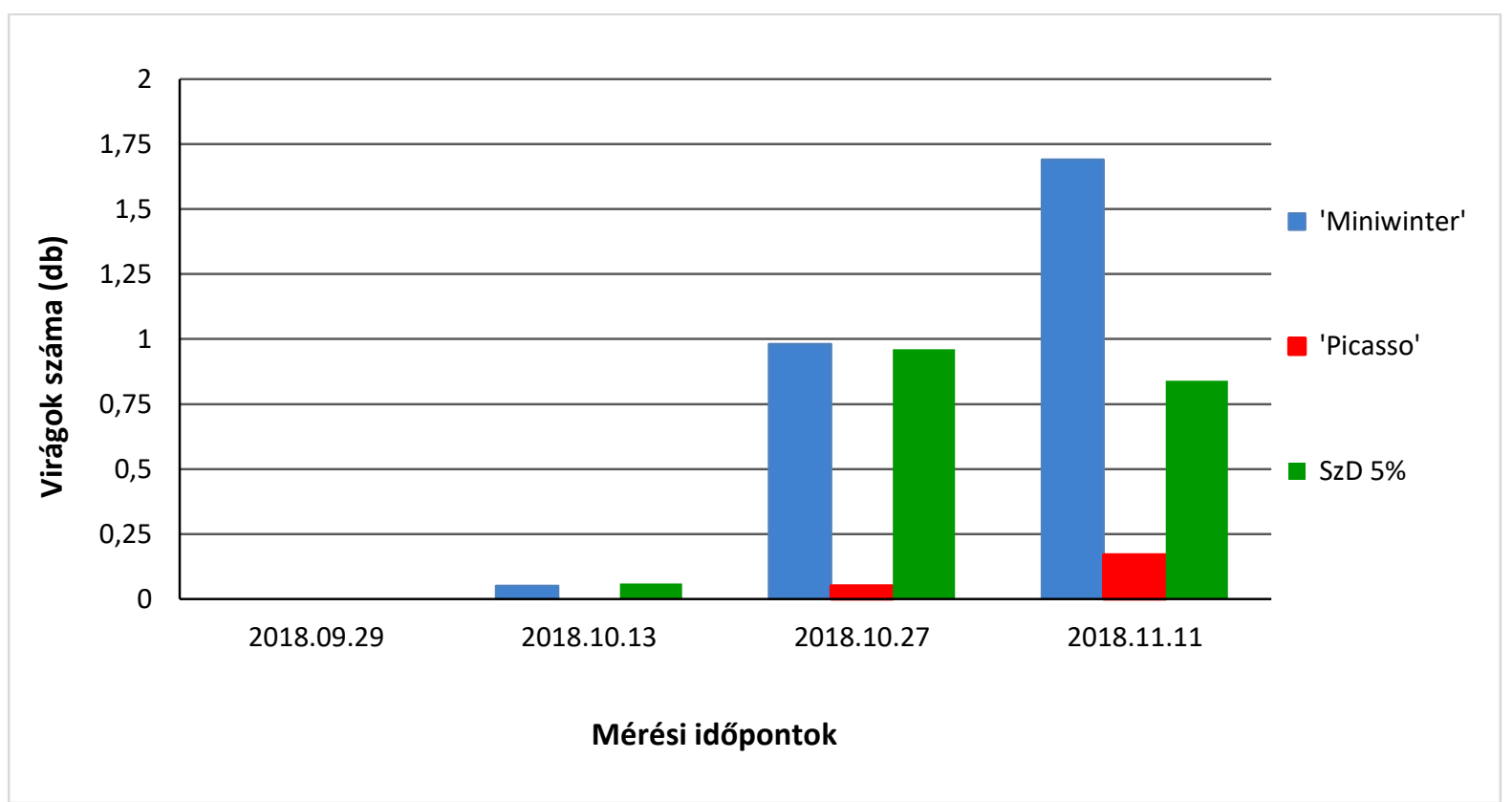

3. ábra: Ciklámen fajták virágszámának alakulása 2018-ban

Forrás: saját ábra 
A 3. ábra mutatja, hogy az első mérés időpontjában szeptember 29-én a mért értékek mindegyike 0 . Ennek oka, hogy ebben az időpontban még nem virágzott egyik fajta sem. A virágzás a második október 13-i időponttól kezdődik. Itt viszont még csak a 'Miniwinter' kezdte kihozni első virágait. Szignifikáns eltérés csak a mérés utolsó időpontjában született 2018. november 11-én. Az itt tapasztalható különbségek azonban szemmel is láthatók. Virágzás szempontjából a 'Miniwinter' sokkal jobban teljesített, mint a 'Picasso' fajta.

\subsection{Levélszám}

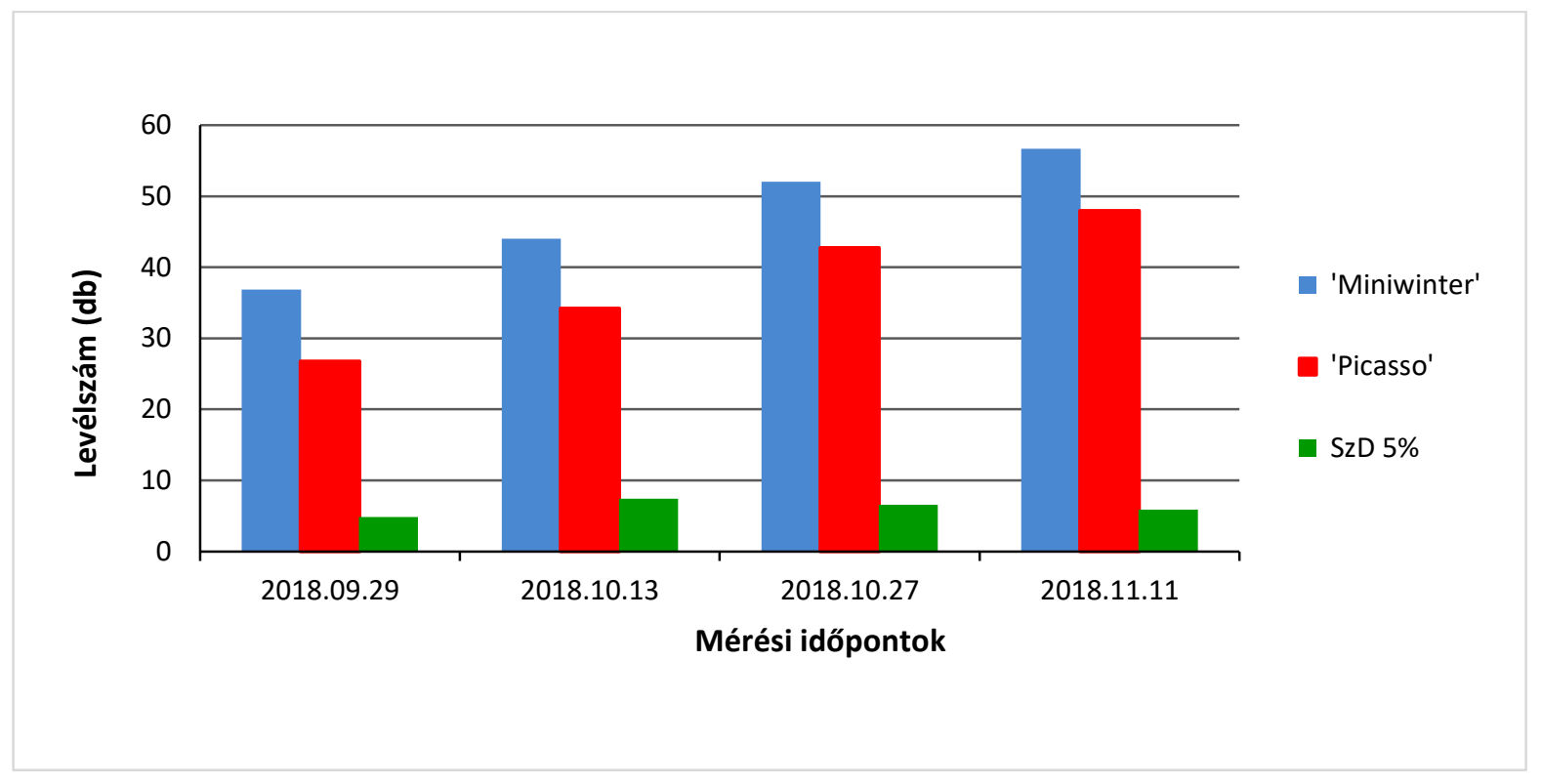

4. ábra: A ciklámen fajták levélszámának alakulása 2018-ban

Forrás: saját ábra

A 4. ábrán látható időpontok mindegyikében szignifikánsak lettek a mért értékek. Látható, hogy a 'Miniwinter' fajta levélszáma lényegesen magasabb, mint a 'Picasso' fajtáé. Tehát a növények is tömörebb állományúak, zömökebbek lesznek a nagyobb levélszám esetén.

\section{Következtetések}

Az elvégzett kísérletből számos következtetést vonhatunk le a két fajtára vonatkozóan. Átmérő szempontjából egyértelmüen a 'Picasso' fajta lett a nagyobb. Ebböl következtethetünk arra, hogy a nagyobb méret miatt az egy négyzetméterre jutó növények száma csökken, amely viszont a termelési költségeket fogja megváltoztatni. Hiszen ha egy négyzetméteren kevesebb növényt tudunk elöállítani, akkor a megtermelt jövedelem is kevesebb lesz abban az esetben, ha egyforma értékesítési árat szabunk meg a két fajtának. Ugyanakkor a nagyobb átmérő miatt a használt csomagolóanyag is változhat, mely szintén befolyásolhatja az előállítás költségeit.

A következő megállapítást a levelek számára vonatkozólag lehet tenni. A kísérlet során a 'Miniwinter' levélszáma lényegesen nagyobb, mint a 'Picasso' levélszáma. Tehát a növények tömörebbek, mely a ciklámen piacon előnyt jelent. Felmerül a kérdés viszont a növényvédelemre vonatkozóan. A tömörebb-szorosabb levélállás az őszi csapadékos és párás időben fokozhatja a botritisz fertőzés kialakulását, mivel a kontakt permetezőszerek nem hatásosak sürü lomb esetén, hiszen nem jut be a növényvédőszer a növény belsejébe. Ez nem megfelelő preventív technológia 
esetén komoly anyagi kiesést okozhat, hiszen azok a növények, melyeket a gombás fertőzés a lombozat belső részén támad meg gyakran válnak kidobott áruvá. Ezzel szemben a 'Picasso' lombozata lazább, jobban szellőzik, így a fertőzés veszélye is alacsonyabb.

Szintén fontos következtetés, hogy a levelek száma milyen összefüggésben van a virágok számával. A 'Miniwinter' nemcsak több levéllel, de több virággal és bimbóval rendelkezett a kísérlet alapján. Ennek egyik fontos oka lehet, hogy a nagyobb levélszám nagyobb előállított asszimilátát jelent a növény számára, ezáltal pedig nagyobb mennyiségű virágot tud a növény kinevelni.

Fontos megemlíteni a virágok számát és a virágzási időpontokat is. A kísérlet során a 'Picasso' fajta rendelkezett a kevesebb virággal és 1,5-2 héttel később is kezdett virágozni, mint a 'Miniwinter'. Ez a termelöknek rendkívül fontos információ lehet, mivel a vásárlók a minél több virággal rendelkező ciklámeneket tartják a dekoratívabbnak. Ugyanakkor a termesztés időzítése miatt fontos ismerni a virágzás kezdetét is, így mindig készárut tudunk biztosítani és a termesztési és értékesítési időt is széthúzhatjuk ennek függvényében.

Végezetül pedig fontos megemlíteni a bimbószámot. A dísznövény kereskedelemben a virágok száma mellett egy termék piacosságát annak bimbószáma is meghatározza. Ezért is fontos ennek a paraméternek a mérése is. A vásárlók minél hosszabb ideig szeretnék, hogy a vásárolt dísznövény díszítse otthonukat, környezetüket. Ezért fontos számukra, hogy minél több később nyíló bimbó legyen a növényeken, minél tartósabb legyen a virágzás. Ebből a szempontból szintén a 'Miniwinter' teljesített jobban a kísérlet során.

Megállapítható tehát, hogy megfelelő termesztéstechnológia mellett a 'Miniwinter' fajta lett a kedvezőbb választás azonban érdemes a kísérletet a következő évben megismételni, hogy biztosabb eredményeket kapjunk.

A kísérlet során több javaslat is született. Elöször is a 2018. évi kísérletet meg lehetne ismételni a következő évben, esetleg más fajtát is kipróbálni. Érdemes lenne a kísérletben kitérni az alkalmazott cserepek méretére is, hogy az így kapott növényeknél a termesztő közeg mérete miként befolyásolja a virágzást, a levélszámot és az átmérőt.

\section{Köszönetnyilvánítás}

Köszönettel tartozunk a kutatás támogatásáért, amely az EFOP-3.6.2-16-2017-00012 „Funkcionális, egészséges és biztonságos élelmiszer termékpálya modell kidolgozása a szántóföldtől az asztalig elv alapján, tematikus kutatási hálózatban" pályázat keretében valósult meg. A projekt a Magyar Állam és az Európai Unió támogatásával, az Európai Szociális Alap társfinanszírozásával, a Széchenyi 2020 program keretében valósul meg.

\section{Irodalomjegyzék}

[1] A. B. Graf (1992): Tropica. Color cyclopedia of exotic plants and trees. Fourth edition Roehrs Company, New Jersey p. 986.

[2] Gerbár J. (1979): A ciklámen. Mezőgazdasági Kiadó, Budapest, 1979

[3] Glits M. - Folk Gy. (2000): Kertészeti növénykórtan, Mezőgazda Kiadó - Budapest pp. 439-442.

[4] J. Parker - M. Malone. (2006): Flóra. A világ legnagyobb kertészeti enciklopédiája. I. kötet Athenaeum 2000 Kiadó, Budapest p. 450.

[5] Király G. (2009): Új magyar füvészkönyv. Magyarország hajtásos növényei. Határozókulcsok Aggteleki Nemzeti Park Igazgatóság, Jósvafö p. 325.

[6] Lévai P. (2000): Dísznövénytermesztés I. Főiskolai jegyzet. KF Kertészeti Főiskolai Kar kiadványa

[7] Merényi A. (2017): Ökológiai szemlélet a dísznövénytermesztésben; Kertészet és szőlészet, 2017. (66. évf.) 2. sz. 2627. old.

[8] Merényi A. (2019): Kertészeti szakmai hírek, rendezvenyek; https://viragoshirek.hu/a-ciklamen-es-a-feny/ (2019. 11. 05.)

[9] Schmidt G. (2002): Növényházi dísznövények termesztése Mezőgazda Kiadó, Budapest. pp. 485-491.

[10] P. Adriaanse (2013): A comparison of growth media on cyclamens in a controlled environment, ISHS Acta Horticulturae 1055

[11] http://kertesztananyag.hu/modern-disznovenytermesztes/cserepes-disznovenyek-termesztese (2019.10.31.)

[12] http://www.floretum.hu/dokumentumok/termesztesi tanacsok/Cyclamen.pdf (2019.10.30.)

[13] https://www.plantgrower.org > cylamen_production Keys to cyclamen production - Plant Grower (2019.10. 30.) 